\title{
24
}

\section{A new engine for pragmatism in the international security order?}

\section{Greg Austin}

In 2002 China appointed senior diplomat Wang Shijie as special envoy to the Middle East and in 2003 it approached NATO with a proposal for a formal relationship similar to that which Russia has with the Atlantic alliance. ${ }^{1}$ In recent years China has gradually been resuming its economic aid programs to poorer developing countries at the same time as it has been intensifying its efforts to shape global arms control and proliferation regimes and expanding the reach of its defence diplomacy. China's international security policy has gone global. Is this a gradual accretion of global interests following on the internationalisation of China's economy, or does it represent a more deliberate effort by China to return to an international security strategy with the sort of global reach China pursued in the 1950s and 1960s?

If China were pursuing a global reach now, it would be for far different reasons than in the 1950s and 1960s. But it is worth recalling that era. At that time, China supported wars by national liberation movements in Africa through the provision of military and economic aid, it supported the export of communism in Southeast Asia, and it engaged in proxy wars against both the former Soviet Union and the United States. By 1974, China began abandoning these global aspirations and retreated to a periphery-oriented national security strategy while it undertook important domestic economic and political reforms.

China's leaders now appear to be abandoning the periphery-dominated national security strategy in favour of a new international security strategy with gl obal reach. According to well-placed sources in Beijing, China's leaders decided through the course of 2002 that this was the only choice open to them in the face of continuing 
US strategic pressure on them over Taiwan and in light of the significant changes in the international situation, especially on their periphery. ${ }^{2}$

China's emerging globally-oriented national security strategy has three main characteristics: it is defensive, pragmatic, and gives a low priority to use of military force. In all three respects, it contrasts with the current US national security strategy, which is pre-emptive (offensive), ideological and gives a high priority to use of military force. ${ }^{3}$ It is this contrast, particularly between the pragmatism of China's new global strategy and the ideological pretensions of the US strategy that is the main subject of this chapter.

Five main catalysts have prompted the shift in China's national security strategy

- changes in US national security policy since 11 September

- the subsequent, further deterioration in relations between the Islamic world and the West

- the opening of NATO to a global role and the securitisation of the European Union

- the deepening and intensification of US-Taiwan military relations under a Democratic Progressive Party (DPP) presidency in Taiwan

- the reintroduction of US counter-proliferation military planning for North Korea and the subsequent moves by Japan to upgrade its military posture.

Each of these is, self evidently, sufficient in and of itself to affect Chinese perceptions of the international security order. Together, these five catalysts look likely to have a profound effect on China's fundamental national security strategy. We have seen strong early signs of a shift away from a periphery-based strategy to one with a global compass. It will remain to be seen whether the shift is consolidated. This chapter does not describe the five catalysts separately. Rather, it seeks to draw them together through an overview of the increasing US strategic pressure on China's periphery. It then looks briefly at China's possible responses. It is here that the hypothesis about China as an engine for positive change in the international security order is canvassed. The chapter concludes with some brief musings about the impact of this analysis on some theoretically derived propositions about China.

\section{CHINA'S SENSITIVE AND VULNERABLE PERIPHERY}

China's leaders have appeared to be 'border sensitive' in ways that have often puzzled outside observers. This puzzlement was exacerbated by the extravagant approach taken by China in the 1950s to the limits of 'historical China' and by the 
belligerent approach of China across virtually all of its borders between 1962 and 1969. But, apart from the Cultural Revolution period, China has not had a disposition towards borders and sovereignty that has been all that different from that of other states (Watson 1966:19-20, 212-3). That is, except in one important respect. For China, the final chapter of national territorial unity has yet to be written. The civil war may be over, but for many in China national unity has not yet been restored. China is the only country in the world, and therefore the only major power, that is facing a serious 'secession' problem from a territorial entity with a large economy, powerful armed forces and global diplomatic representation (albeit unofficial). The decades of diplomacy and international noise that have surrounded Taiwan's international status have to a certain extent numbed outside observers to the true sensitivity of this fundamental consideration of China's nationhood. The resumption of Chinese sovereignty over Hong Kong in 1997 and Macao in 1999 has created a new time pressure on leaders in Beijing to reunify China. However these pressures work out (and a peaceful settlement should not be excluded) the defining aspect of China's international relations is now, and will be for coming years, the approach taken by Taiwan to the question of China's national unity and dignity.

What marks out the 1990s as substantially different from the 1970 s and $1980 \mathrm{~s}$ is that China's leaders have begun to be far more conscious and far more defensive of the country's vulnerabilities on its periphery. This mood has been facilitated in some senses by a rise in China's physical capacity to control its borders as defined in a legal, technical sense but it has also been provoked by a growing sense of incapacity to contain and control threats in other dimensions. For China's leaders, the boundaries of their power-their international borders in both physical and social senses-are now facing multiple and intensifying threats. In some areas, the threat is one of legal, technical separation (as in Taiwan), while in others (such as Tibet and Xinjiang), the threat is seen only as one of resisting and repudiating the remit of the central state.

For 16 years (1979-95), China was prepared to assign a lower priority to borders as a source of threat relative to a vision of borders as a source of opportunity, or even of economic necessity. As Chinese scholar Tianbao Zhu pointed out in a recent article, Chinese leaders must now choose whether they will continue to accept that prioritisation (Zhu 2001). They are being pushed in the direction of change both by rising nationalist conceptions of the country's borders and by an unambiguous and radical stepping up of international and domestic repudiation of 
the leadership's remit. As Jiang Zemin noted in the concluding four paragraphs of his report to the $16^{\text {th }}$ Communist Party Congress in November 2002, "it is essential... to bring about the great rejuvenation of the Chinese nation', a formula which he repeated one paragraph later, before noting in the third paragraph that China had to be "keenly aware of the rigorous challenges brought about by the ever-sharpening international competition'. ' He noted earlier in the speech that 'uncertainties affecting peace and development are on the rise' and that 'hegemonism and power politics have new manifestations'. And that the Party had faced a number of 'unexpected challenges bearing on China's sovereignty and security' since $1989 .{ }^{5}$

The December 2002 Defence White Paper noted that a 'new serious disequilibrium has occurred in the balance of military power' (PRC State Council Information Office 2002)-a reference to US military pre-eminence. The White Paper listed periphery security as one of the few internationally oriented tasks of the country's security policy ('striving for a favourable environment in China's periphery'). The Paper also reported that Taiwan separatists remain the biggest threat to security in the Taiwan Strait (and hence on China's periphery), and that they were being encouraged by a few countries selling weapons to Taiwan. It reported that 'China resolutely opposes... any country entering into a military alliance with Taiwan'. Jiang's speech called on China to 'strengthen state security, keeping vigilance against infiltrative, subversive and separatist activities'.

\section{Geopolitics of the China periphery and the US political challenge}

In Taiwan, Tibet and Xinjiang, China's leaders have for many years seen themselves as facing threats to the country's national integrity and territorial sovereignty. Except at the most general level, these three problems have not really been linked either in concrete practicalities or in perceptions since the CIA abandoned its covert political agitation inside China some three decades ago. The specific circumstances of Taiwan, Tibet and Xinjiang remain quite different and there has been little reason to see them as connected. But strategic policymakers in Beijing are beginning to see these once distinct problems as having new common threads that make them together a much higher order of security problem than any of the three cases had represented individually.

The single most important thread in this evolving perception is the view that, since President George W. Bush came to power in January 2001, the United States has been positioning itself to limit China's potential strategic power and has been 
using developments in these three areas to do that. Even to the non-specialist eye, this challenging trend in US policy has been relatively conspicuous in connection with Taiwan, especially in the rejuvenation of the US-Taiwan military relationship to levels unprecedented since 1979, and now little different from the alliance that was abandoned in that year.

But, as this chapter contends, it can be seen also in the cases of Tibet and Xinjiang, albeit in more complex or attenuated ways. The insertion into Central Asia in late 2001 of a potentially permanent US military presence can only magnify the vulnerability and risk that China feels in light of increased US military support for Taiwan. China's leaders do see the US military presence in Central Asia as positive in that it contributed to the removal of the Taliban, but they see it on balance as negative in that it will position the United States better to influence and challenge China's management of its internal affairs in Xinjiang. This reflects the essentially political nature of the new US challenge on China's periphery. And it is the political dimension that is evident in new US positioning on Tibet. There is no US military involvement in Tibetan 'separatism', nor is there likely to be much potential for such involvement. But China's leaders see even US political pressure on Tibet issues as gathering momentum, and as an intensification of US pressure on China as a whole for 'peaceful evolution' of China domestically and for containment of it on the international stage.

The evolution of US-China relations through 2002 has been sufficiently positive to dampen some of the more visible forms of tension between the two nations. In particular, the US need for China's support in Security Council votes on possible war with Iraq in late 2002 overshadowed and even contained some of the emerging negative trends in US-China security relations that were so visible in 2001. But this chapter contends that the underlying fundamentals remain negative. China's support for the US (and UK) position in the UN Security Council is based on shared values to some degree but is also part of China's strategy for responding to the new US strategic challenge that is emerging on its periphery.

The history of international relations shows convincingly that strategic pressure by one major power on another's periphery areas is a recipe for instability in international order. Where the power being subjected to pressure is a rising power, with not just a history but a historiography premised on recovery from national humiliation or fragmentation, the risk of strategic instability is even greater. This sort of consideration was prominent in the ideology of aggression advocated by the 
regimes in Germany and Japan prior to the Second World War. Thus, recent US positioning on each of the three problem areas arguably presents a new security challenge not just for China but for the international community as a whole. As a recent study from a US ally put it, our 'interest in a stable, cooperative, prosperous future for Asia is threatened by the possibility that America and China might drift into animosity or even war in coming years. The risk of this outcome is not high, but it is real and significant' (Australian Strategic Policy Institute 2002).

Each of China's three periphery problems (Taiwan, Tibet and Xinjiang) is becoming more bound up with US global strategic power, an expansion of US regional alliances, and a reorientation of US military strategy and force deployments. The Bush Administration has vigorously followed up on the Clinton Administration's commitment to 'democratic expansion'. And Bush's first review of strategic policy in 2001 concluded that the most likely potential threat for major war in the future would come from China. As a result, the United States has been undertaking more and more concrete measures in both political and military strategy that directly impinge on China's periphery.

Over the last decade, there has been an escalating contest of ideas in Beijing, Washington and Tokyo about the future balance of power in East Asia. With both China and the United States seeing the resolution of Taiwan's status as reflecting seriously on their credibility as great powers, US planning for Taiwan-related contingencies is not just about Taiwan's status but has become part of a bigger balance of power contest with global ramifications. In February 2002, the Director of the CIA, George Tenet, told a Congressional committee that China's cooperation with the United States in the war against terrorism changed none of the fundamentals of the long-term strategic competition between the United States and China. That cooperation, he said, would not deflect China's bid to emerge as a power likely to challenge US strategic pre-eminence in Asia; and China's cooperation did not reduce the need for the United States to prepare for the contingency of military confrontation with it. ${ }^{6}$ There are other statements by senior US officials that explicitly discuss the need to contain China's rising power.

The September 2002 National Security Strategy of the United States represented a further challenge to China, not because of the changes in military deployment that it foreshadowed, but for the return by the United States to a Kennedy-esque ambition of going anywhere and paying any price to to defend freedom. For China, the reference in the Strategy to the US intention to 'defend the peace by fighting 
terrorists and tyrants', was a reference (in the second word 'tyrants') to the Chinese leadership (Government of the United States of America 2002). The suggestion in that document that '[i]n time, they [China's leaders] will find that social and political freedom is the only source of national greatness' is reasonable enough. But until they do accept liberal pluralism, language like the following seems to place them at odds with the main thrust of the US strategy: 'We seek...to create a balance of power that favours human freedom: conditions in which all nations and all societies can choose for themselves the rewards and challenges of political and economic liberty'; and 'The United States will stand beside any nation determined to build a better future by seeking the rewards of liberty for its people' (Government of the United States of America 2002:n.p.).

We can diasgaree on what these words mean, but over the last decade there has been an unambiguous intensification in US national security strategy of measures premised on the need to prepare for the contingency of military confrontation with China as a possible evolution either of an emerging balance of power contest in Asia or as a result of some Taiwan crisis. According to veteran China-watcher, Jonathan Pollack, what we are seeing in the United States is not threat-based planning, not capabilities-based planning, but 'possibilities-based planning'.7

\section{Taiwan and the Western Pacific}

Beginning in 1995, China has undertaken a series of military manoeuvres designed to intimidate Taiwan and its international supporters into reversing Taiwan's move away from the 'one China' principle. Resort to such a drastic measure was evidence that, even then, China felt that it was losing ground on Taiwan. In its White Paper on Taiwan, issued in 2000, China imposed a new condition that indicated its continuing sense of losing ground. China insisted for the first time that Taiwan could face use of force if it sought to put off reunification indefinitely. In November 2002, President Jiang said bluntly that China was looking for a positive move towards reunification 'at an early date'. ${ }^{8}$ As two prominent US scholars observed in 1999, 'Taiwan is perhaps the only external issue where raw emotion and nationalist fervour trumps the realpolitik calculations that normally govern China's external policy' (Lampton and May 1999). The reason for this is that the 'Beijing leadership believes it could not remain in power if it buckled on an issue central to Chinese nationalism'. By late 2002, Taiwan was not backing down and it had more international support than ever, especially from the United States. In response, China was determined to show its 
resolve and refused to back down. In mid October 2002, it signalled a possible expansion of its military pressure on Taiwan by dispatching one of its warships on an unprecedented cruise parallel to the east coast of Taiwan.

The United States and its allies in the Western Pacific, especially Japan and Australia, are now positioning themselves, in political and strategic terms, for a new confrontation between the United States and China over Taiwan. The United States and its allies reacted strongly to China's military intimidation of Taiwan in 1995 and 1996. The United States deployed two aircraft carriers, Japan hurriedly completed a number of measures with the United States to extend US military access to its territory, and Australia's Defence Minister declared his country's readiness to join combat alongside the United States if hostilities broke out. While these reactions were appropriate, there is little doubt that this military response by the United States and its allies was seen by Beijing as an unacceptable intervention in its 'domestic' Taiwan problem and only encouraged China in subsequent years to intensify its military readiness opposite Taiwan.

The eight years since 1995 have seen a gradual escalation in military preparation by China and the United States for the contingency of military hostilities of some sort associated with Taiwan. For example, China has deployed some 300 mediumrange missiles to its coastal areas opposite Taiwan, and reliable sources estimate that the number will rise to 800 by 2006. In the same period, China has conducted large-scale military exercises in the Taiwan Strait. For its part, the United States has been consistently enhancing its military capabilities in the Western Pacific. While this has not so far seen dramatic increases in US military forces permanently deployed to the region, the United States has steadily improved its infrastructure and operational readiness by

- reactivating military facilities on Guam to provide forward-basing options for China-related contingencies

- conducting carrier battle group exercises in the South China Sea (on one occasion at least involving two carriers)

- carrying out US carrier transits of the Taiwan Strait

- extending US-Japan mutual support arrangements for Korea-related and Chinarelated contingencies in the second half of the 1990s (Austin 1997)

- rejuvenating the military alliance with the Philippines during the Clinton Administration (Austin 2003) 
- notifying of its intent to withdraw from the ABM treaty (this was not directed at China but is seen by it as a threat since it opens the way to develop theatre missile defence technologies which China suspects will be transferred to Taiwan).

The forced landing on Hainan Island in April 2001 of a US military intelligence aircraft that had been involved in a mid-air collision with a Chinese air force fighter highlighted publicly the intensity of US military intelligence collection efforts against China. And that was even before the new Bush Administration had completed its first review of US strategic policy, which elevated the possibility of major war with China to a central plank of long-term US strategic planning.

Citing China's continuing military intimidation of Taiwan as the justification, the Bush Administration took US policy towards Taiwan on a more confrontational path by radically enhancing its military relationship with Taiwan. In the second week of March 2002, the United States permitted a visit by Taiwan's Defence minister to participate in public and private discussions of his official portfolio interests, even though the United States sought to pass off the visit as 'unofficial'. ${ }^{9}$ This visit was the first substantive one by a Taiwanese foreign affairs or security minister since 1979. The minister held a 100-minute meeting with Deputy Secretary of Defense Paul Wolfowitz. Also in March 2002, news broke of a Pentagon document detailing a nuclear posture review by the Bush Administration that called for US planning for the use of nuclear weapons in a Taiwan Strait contingency-a report that Chinese officials predictably described as 'shocking' (Arkin 2002). Other moves include

- new arrangements for military exchanges with Taiwan

- normalisation of the timing and manner in which the United States approved arms sales to Taiwan

- expansion of the scope of arms sales to Taiwan

- committing to pursuing combat interoperability between US and Taiwanese armed forces

- committing to supporting substantial reform in Taiwan's administration of defence policy and development of joint force operational capability.

\section{Tibet, India and US policy trends}

In contrast to the relationship between Beijing and Taipei, the situation in Tibet is far less dramatic for the Chinese leadership on a day-to-day basis. Despite this, it is no less threatening. On the one hand, Beijing controls the territory in Tibet and has in place a highly developed system of public administration. This is backed by a large 
number of uniformed personnel and residents who are not of Tibetan origin, but are migrants (or the children of the migrants) sent there in the past four decades by Beijing to provide a substantial population base for continued rule by China. The enemy for Beijing in Tibet is the authority of a religious leader who commands no armed forces, who is not supported by any quasi-military alliance with the United States, and who preaches non-violence. There is therefore no question of Tibet as a political entity continuing to resist Beijing's efforts to control it physically, as with Taiwan. This is not an issue of re-unification.

On the other hand, there is a Tibetan government in exile, located in Dharamsala in northern India. The spiritual leader of the Tibetans, the Dalai Lama, vigorously cultivates international support for his resistance to Beijing's rule, without ever really being too precise about his long-term political ambition for Tibet. He says he is interested in increased autonomy for the local (non-Chinese) Tibetan community, but Beijing fears that he really wants independence. And the Dalai Lama has recently rebuked Beijing publicly for lack of response to his conciliatory approach, a rebuke that carries with it the implication for Beijing that the Tibetan government in exile will more directly advocate total independence from Beijing. The authorities in Beijing continue to suppress the collective activities of Buddhist monks in Tibet, and thereby continue to fuel not only resistance by Tibetans to its rule but also international support for this resistance. Thus, while this is not an issue of reunification, it is for Beijing an issue of national integrity and internal security on almost the same level of complexity as the Taiwan problem.

For Beijing, the Tibetan problem is getting worse. Sentiment in Western countries in favour of Tibetan independence continues to snowball. The number of legislative resolutions or other measures taken in Western parliaments to register disapproval of Beijing's style of rule continues to grow. The Dalai Lama has extended his international profile. China's main assets (physical control and transmigrants) offer no guarantee of any sort in the absence of other fundamental changes in the loyalty of the local population. The cases of the former Soviet republics, especially Estonia, where the former Soviet Union had military and internal security forces and where some 40 per cent of the population identified as ethnically Russian, do not reassure Chinese leaders that their possession of such assets in Tibet offers any ultimate protection against eventual political separation.

Where is the US hand in propping up or bolstering Tibetan resistance to Chinese rule? One scholar has rightly observed that it has been the Congress and not the 
Administration that has maintained interest in the 'Tibet cause' in the United States (Knaus 2000). There is certainly no public evidence of direct use by the US Administration of any military strategic instrument, and the Administration's public face on Tibet is one of acceptance of Chinese sovereignty. A series of Congressional initiatives on Tibet were taken most visibly in 1987 after the Dalai Lama addressed the Congressional Human Rights Caucus (Knaus 2000). But President Bush Senior initiated the 'drop-in' meetings between the Dalai Lama and the President in the White House, a practice continued by Clinton and George W. Bush.

With the emphasis in the Clinton Administration on the expansion of democracy, new moves were taken by parts of the US government to support Tibetan resistance to Chinese rule. For example, when Clinton visited India, he signed a joint declaration with the Indian Prime Minister which provided for the opening of an office there of the US National Endowment for Democracy (NED), an office which has provided low levels of funding to Tibetan exile groups. ${ }^{10}$ Some Chinese sources refer to the NED as a CIA front. In the Clinton period, the US Senate passed on 9 March 2000 a bill to designate 10 March as the 'national day' of Tibet (China Daily Online, 9 March 2001).

The political contest between Washington and Beijing over Tibet has escalated under the Administration of George W. Bush. In May 2001, the US Congress (both houses) passed the Tibet Policy Act, which declared Tibet-including Tibetan nationality areas in parts of four neighbouring Chinese provinces--to be an 'occupied country, ${ }^{11}$ and called on the US government to undertake a range of measures including

- reappointment of a Special Coordinator for Tibetan Issues within the State Department

- annual reporting to Congress on progress in US efforts to get a Tibet-China negotiation on autonomy under way

- imposition of conditions on US-supported multilateral aid projects in Tibetan areas of China

- application of best efforts to establish a State Department office in Lhasa

- stepping up advocacy by the US State Department of an end to 'all interference' by Beijing 'in the religious affairs of the Tibetan people'

- increasing the visibility of Tibetan groups and Tibetan issues within the United Nations. 
The Act also provides for Tibet to be an issue of discussion between the USEuropean Interparliamentary Group. In response, on 17 May 2001, the Bush Administration gave to Undersecretary of State for Global Affairs Ms Paula Dobriansky the assignment of US Special Coordinator for Tibetan Affairs. Her duties are to 'help preserve Tibet's unique cultural, religious, and linguistic heritage'. Dobriansky is the highest-ranking official to hold this post since it was set up in 1997.12

On 5 March 2002, a Resolution was introduced into the House of Representatives by 42 members calling on the Bush administration to 'give serious consideration to recognising the authorities of Tibet who are currently exiled in Dharamsala, India, as the legitimate representatives of Tibet' if they cannot reach an agreement with Beijing within three years that 'provides for the political autonomy of Tibet'. ${ }^{13}$

So, at many levels, the Act and other recent Congressional moves on Tibet represent a significant expansion of the 'internationalisation' of the Tibet issue, something which Beijing has always opposed. If one takes as a precedent the way in which Congressional opinion on Taiwan has helped to shape US Administration policy in the last decade, then these Congressional measures on Tibet will only be viewed in Beijing with great concern.

\section{Xinjiang and the shifting alliances of Central Asia}

Some members of the Uighur community and some other Turkic ethnic groups have been waging a low-level campaign of sabotage and murder against the Chinese government in support of claims for independence from China. Their violent resistance to Chinese rule first resurfaced between 1989 and $1993,{ }^{14}$ died down somewhat in 1994-95, and again intensified after February 1997 (South Asia Analysis Group 1999). The rise in armed Uighur nationalism can be attributed in part to the service in Afghanistan during the 1980s of Chinese citizens of Uighur nationality; and in part to the relatively easy interchange that had existed between radicals in Pakistan and Western China. A number of the violent activists in Xinjiang have been trained in Pakistan.

The Xinjiang Uighur Autonomous Region (XUAR) retains many appearances of a colony of China. ${ }^{15}$ Except in the capital and a few other places, it has highly segregated and mutually antagonistic populations. It has a violent (though low intensity) rebellion of the indigenous population, and an irrational and highly centralised 
system of economic exploitation, through the Xinjiang Production and Construction Corps (somewhat reminiscent of the British East India Company in its heyday). ${ }^{16}$ There are marked differences between northern parts of the XUAR, including cities like Urumqi and Turfan, which are 'Sinicised', have quite high proportions of Han Chinese, and are less troublesome, and the southwestern parts around Kashgar, where the Uighur community accounts for 90 per cent of the population, where modernisation has not been profound, where there are deep-seated inter-communal tensions, and where there is a pervasive 'wild west' atmosphere (Kemenade 1998:403-4).

According to sources in Beijing, the Chinese government now feels it is losing the fight against the Moslem rebels. The reasons cited for this by Beijing sources are as follows. ${ }^{17}$ There is now a net outflow of Han Chinese from Xinjiang. This has come about because the policy of migration of Han Chinese to Xinjiang was a policy of forced migration, when jobs were assigned by the Party and people had little choice but to go where they were sent. Now that China effectively has a free labour market and its controls on residency have largely evaporated, many of the forced migrants to the West are returning to their original homes (for family reasons) or to other places in the richer provinces (for economic reasons). Even a number of Han Chinese born in the west find it more attractive for economic reasons to migrate eastwards. This net outward migration is a long-term problem for the Chinese leadership, and though it can be corrected over time with special incentives, the issue bears heavily on leadership calculations of the nature of the problem. There are other indirect signs that China is losing control, and these include a rapid increase in the number of illegal mosques and religious schools.

The rebellion in Western China weighs even more heavily on Chinese leadership perceptions of internal security because official sources in Beijing believe that China has lost control of infiltration across the borders with Tajikistan and Kyrgyzstan, two tiny countries of Central Asia facing immense problems of governance and armed incursions of their own. China has significantly increased its military relations with Kyrgyzstan at least and is providing support to the development of its border surveillance programs. But these programs are at a low level and the flow of weapons, money and drugs to support the operations of the rebels in Xinjiang has increased in recent years. Chinese sources make it clear that China does not have the capacity to seal its borders in the west. Chinese military and police assets even now have to rely on citizen support for surveillance of the borders. Since long stretches of the 
border are in very sparsely populated areas, the citizens are not much help-even if they were well disposed to Beijing or the government, and most in southwestern Xinjiang are not.

China supported US military intervention in Afghanistan to attack and root out AlQaeda and Taliban forces. China had also supported a series of Security Council resolutions beginning in 1998 calling on the Taliban to stop harbouring (and to hand over) indicted terrorists. ${ }^{18}$ So, it could be argued that the arrival of US military forces in Central Asia in the war against terrorism is not of great concern to Beijing and is indeed welcomed. At one level this is true and it is not difficult to find commentaries in the Chinese media to this effect.

But the leadership view is more likely negative on balance, taking much the same view as has often appeared in Chinese open source commentaries. ${ }^{19}$ While the more negative public commentaries were published prior to China's more fulsome welcoming of the US military action in Afghanistan, they are still useful as a reflection of the basic instincts of at least some Chinese leaders. Much earlier commentaries were quite strong, painting US strategic intentions in Central Asia in a negative light, suggesting that the United States was trying to bring the region 'under its security system', and that it was trying to gain control of the region's energy resources. ${ }^{20}$

China's military leaders in particular are not happy with the expansion of Europe (OSCE and NATO Partnership for Peace) to their western borders. They are even less content about the new US presence in Central Asia after 11 September 2001. It should be noted that the main requirement from China's point of view in support of a temporary US presence in Central Asia at that time was an internal security one. China had to put aside its geo-political concerns in the interests of eliminating the threat of the export of revolution to Xinjiang from Afghanistan, Pakistan and some of the Central Asian states. China also no doubt saw virtue in being seen to be friendly to the United States in its moment of great need from the point of view of trying to make a dent in US public opinion. But now that the immediate threat of export of revolution has been reduced significantly, the geopolitical concerns will almost certainly begin to re-emerge.

Until the US military presence arrived in Central Asia, China had been quite successful in shaping the geopolitics of the region. Along with the former Soviet Union, China had established in 2001 the Shanghai Cooperation Organisation, an outgrowth of the multilateral border negotiating forum, the Shanghai Five, that had 
been in place since the collapse of the USSR ${ }^{21}$ China's active leadership in formation of the Shanghai Cooperation Organisation (SCO), which included Jiang Zemin attending a summit meeting in Dushanbe, the capital of Tajikistan, is one of the most visible manifestations of the seriousness with which China views the geopolitics of the region. The SCO has both regional and global ambitions. At the regional level, it provides a formal legal framework for cooperation in anti-terrorism and border security, among other regional security issues such as the illegal arms trade. At the global level, it has the ambition of providing the foundation for a new international order ${ }^{22}$ premised on multipolarity and the 'renunciation of unilateral military superiority in contiguous areas'. ${ }^{23}$ But the organisation gives priority in the security sector to regional security. In this sphere, the determination of both China and Russia to apply maximum resources consistent with political constraints, such as sensitivity about deploying troops across borders, should not be underestimated. In forming the SCO, both China and Russia saw the existing and emerging threats in Afghanistan and Central Asia as among the most serious they then faced.

But in geopolitical terms, the fate of the SCO now seems to hang in the balance and the organisation will have to go through the next few years under competing pressures. On the one hand, leaders of all member states share China's very hardline approach to internal security and national unity. It would appear at first glance that they should easily be able to continue to cooperate on internal security matters. But under the influence of the rapid and large scale US strategic insertion into Central Asia after 11 September, cleavages are beginning to show. Uzbekistan failed to attend the last SCO summit, and Russia made a dramatic strategic tilt towards the United States and Europe that can only compromise the embryonic strategic partnership that was emerging between China and Russia. The energy aspect of the Russian strategic tilt, embodied in President Putin's agreement to consult with the United States on oil prices, is one area where this may be felt most keenly by China. After 11 September, China is reported to have taken a decision to establish a strategic oil reserve, partly out of fear of an interruption of Persian Gulf supply, but partly out of concern about long-term access to Central Asian reserves.

The insertion into Central Asia of a potentially permanent US military presence can only aggravate the sense of vulnerability and risk that China feels about the US military support for Taiwan. This has three dimensions. First, a mooted US military presence on China's western border had been portrayed in some Chinese commentaries before 11 September in classic geopolitical terms as encirclement, 
even if that was not the primary motivation for the US deployment once it took place. Second, Chinese leaders could be forgiven for viewing the new US military presence in Central Asia as giving the United States a second theatre option for a military confrontation with China over Taiwan. Third, the US military presence in Central Asia brings with it the inevitable pressure from the United States for political reform and liberalisation in the neo-Communist states there. Chinese leaders almost certainly see this link in Central Asia as likely to lead to more pressure from the United States on China over the political order in western Xinjiang.

\section{CHINA'S INTERNATIONAL RESPONSES: CHALLENGE WORLD ORDER OR SOFTEN ITS EDGES?}

The circumstances analysed in this chapter raise big questions about future directions in Chinese strategic policy. Will these common threads to distinct periphery problems push China's leaders to a different strategic choice than the one they have accepted in the last two decades? Will they hold to the 1989 injunction of Deng Xiaoping of 'First, observing coolly; second, securing our position; third, dealing with things calmly'? (Austin 1998:239). Can China make the domestic political adjustments (significant political liberalisation) to contain its growing problems? Or will they begin to accept that 'strategic breakout' is the only option, and begin to probe in one or other area of the periphery as a means of forcing a realignment of US international alliances on key China issues, especially the status of Taiwan. Or can China go further? Can it begin to contemplate a more comprehensive challenge to US power through a new global rivalry that pits a China-led coalition of non-democratic Third World states against a US-led coalition of democratic industrialised Western states?

For Tibet and Western Xinjiang, China's possible responses stretch across a wide area of domestic policy (nationalities policy, religious policy, political pluralism, regional development programs, legal and police responses). And for all three periphery problems, there is a variety of international policy options (security treaties, economic cooperation, trade and investment, or even coercive diplomacy). China has been trying a mix of policies, including both carrots and sticks, in all three cases and will continue to do so. By 1999, Chinese leaders had agreed to increase their reliance on coercive diplomacy in international policy and increased police repression in domestic policy.

But the four years since the end of the 1990s, when China tilted in the direction of more confrontational responses, have seen only a deterioration in China's domestic 
and international security situations. Relations with the United States and Japan have worsened, as both countries have more openly prepared themselves for military contingencies involving China (or North Korea). In response, as discussed at the outset, there is evidence that China's leaders have decided to shift their national security strategy away from the confrontational choices that rose most visibly to the surface in 1999 and early 2000. China appears to have decided that, if it can't challenge world order, it will soften it.

This has been evident in the change in China's strategy toward Taiwan from a threat-based one to a largely incentive-based one. China now relies on the military threat only as part of a broader political strategy. China has signalled its willingness for the two sides to move forward in cooperative moves on concrete areas of policy without Taiwan's total surrender on the issue of its status. ${ }^{24}$ China is moving more towards treating Taiwan as an equal, at least in negotiating terms if not in formal legal terms. This position is reflected in China's formulation, now a couple of years old, that the 'mainland and Taiwan are parts of one China', a phrase intended to repudiate China's earlier position that Taiwan is a province of China. China wants to give the impression that it is no longer proceeding on the view that it should be the dominant partner. Through 2003, China has shown new determination to find some common ground with Taiwan, going so far as to open the first ever talks at officials' level at the WTO in Geneva in December 2002.

But China's new push to soften the international security order is visible in other ways, not least in its determination to avoid a new military clash on the Korean peninsula and its refusal to take side in crucial votes in the UN Security Council. The appointment of China's first special envoy to the Middle East is another example. China may now have gone somewhat beyond the parameters of Deng's admonition of securing China's position by observing coolly. China appears now to have set itself the positive mission of reducing international tensions through a vigorous globally-oriented security policy of a type not seen in China since 1974.

\section{CONCLUSION}

In the early 1990s, the academic community was divided on China's emerging position in international security affairs. Would its new wealth and power line up behind previous Chinese impulses towards aggression or empire? Or would China become a cooperative member of the international system? Few scholars or 
commentators outside China were prepared then to contemplate a third scenario: China as an engine for positive changes in the international security order.

One decade later, the dominant view in scholarly analysis is that China has recorded an unambiguous commitment to cooperative and stabilising international regimes. Remnants of the 'China-threat' thesis can still be found in the United States, both in scholarly analysis and in positions of power, including the Pentagon, the CIA and the Congress. But most observers are still reluctant to consider China as a potential locomotive force for positive change in the international security order.

It is the contention of this chapter that China is now demonstrating the potential to be such a force for positive change. But the main cause of this does not flow as directly from China's own wealth and growing power, especially its military power, as much from other factors, some of which reflect China's relative military weaknesses. There have been three main factors

- China's perception of a growing US threat to its periphery

- China's perception of its inability to counter that threat militarily

- China's understanding of its capacity to alter the balance of power in its favour through a peaceful settlement with Taiwan.

Thus, in the normal logic of action and reaction in international affairs-as ironic as it seems-China is looking to influence peaceful change in the international security order because of the strategic pressure applied on it by the United States, especially over Taiwan, but in a positive way.

At a superficial level at least, this response seems to suggest that the neorealists and the 'China-threat' advocates might have been right. It does appear, at least at first glance, as though dealing with China from a position of strength has produced positive outcomes. But since the basis of the neo-realist assumption was China's power, not its weakness, something fundamental was wrong in their positioning. Moreover, the neo-realists had premised their argument largely on the need to discipline China and contain it within the existing international security order. They never quite imagined this more complete evolution, with China seeking to change that order by peaceful means.

This author's assessment of China's shift to new global security strategy is partly intuitive, and for this reason the assessment might be challenged on an evidentiary basis. After all, direct access to the strategic thinking of the highest level Chinese leadership is hard to come by. But, whatever the correct assessment of changed 
Chinese strategic perceptions, it is important to note the significant, unambiguous and factually incontestable changes in international security order during the last two to three years and to ask whether they have been sufficiently far-reaching to produce a profound change in China's security policy. If the answer is yes, was the change more likely to be of the sort hypothesised in this chapter or one of a more belligerent nature? Any objective assessment of China's weaknesses in the face of US strengths and power could only find in favour of the former: a determination to work actively around the world to soften existing international confrontations in order to reduce the escalating potential for military confrontation between China and the United States.

\section{ACKNOWLEDGMENTS}

The author would like to thank Dr Willem Van Der Geest and the European Institute for Asian Studies for their support during the research for this chapter.

\section{NOTES}

1 Information provided by a member of staff of the office of the European Union's High Representative for the Common Foreign and Security Policy, Javier Solana, May 2003.

2 Interviews, Beijing, November 2002.

3 These characterisations of US national security strategy should not necessarily be seen as negatives. Rather, as discussed later in the chapter, they are just what the September 2002 National Security Strategy released by President Bush describes.

4 Embassy of the People's Republic of China in Australia, Full text of Jiang Zemin's Report at 16th Party Congress, www.chinaembassy.org.au/eng/37883.html

5 This reference is to the date of Jiang's appointment as Secretary General of the CCP in the immediate aftermath of the Tian An Men suppressions in June of that year.

6 Tenet told the Senate Select Committee on Intelligence on 6 February 2002 that 'China is developing an increasingly competitive economy and building a modern military force with the ultimate objective of asserting itself as a great power in East Asia. And, although Beiling joined the coalition against terrorism, it remains deeply sceptical of US intentions in South Asia. It fears we are gaining influence at China's expense, and views our encouragement of a Japanese military role in counterterrorism as support for Japanese rearmament-something the Chinese oppose:

7 Comments made to the author.

8 Report at $16^{\text {th }}$ Party Congress. 
9 In its 1979 communiqué with China on normalisation, the United States 'recognises the government of the People's Republic of China as the sole legal government of China'. The next sentence in the same article says that '[w]ithin this context, the people of the United States will maintain cultural, commercial, and other unofficial relations with the people of Taiwan'. Even though the United States broke off its formal defence relations with Taiwan at that time, it was understood between the United States and China at the time that the question of the US-Taiwan military relationship, especially arms sales, would be a subject of further US-China discussions. At any rate, the United States made plain in its December 1978 statement on normalisation its expectation that the Taiwan question will be settled peacefully by the Chinese themselves. (This was in contrast to the December 1978 statement of China on normalisation, which said that the Taiwan question "has now been resolved between the two sides')

10 NED was established under President Reagan and is funded by Congress. In 2000, it gave the following small grants to Tibetan groups: 'International Campaign for Tibet- $\$ 30,000$-to support meetings, symposia, speeches, publications and articles designed to improve communication between Tibetans and Chinese; Tibetan Literary Society- $\$ 20,000$-to publish the Tibet Times, a Tibetan language newspaper providing in-depth coverage of Tibetan, local and international issues for Tibetans in Tibet, international audiences and Tibetan exiles; Tibetan Multimedia Centre$\$ 30,000$ - to disseminate news and information about the struggle for a democratic Tibet inside Tibet and China, among Chinese democrats throughout the world, throughout the exile communities of Tibetans in India, and to the Indian public; Tibetan Review $-\$ 20,000$ - to publish and distribute Tibetan Review, a monthly English language news magazine, throughout the Tibetan community in exile and international community'.

1 A measure echoing similar resolutions in earlier years.

12 Her predecessor, Julia Taft, had the rank of Assistant Secretary of State.

${ }^{13}$ See State Dept website, http://usinfo.state.gov/regional/ea/uschina/rez357.htm

${ }^{14}$ Between 1944 and 1950 in the area around Yining, Uighur nationalists managed to establish an independent East Turkestan.

${ }^{15}$ A recent study of Xinjiang in the 1990s, albeit one based on fieldwork mostly conducted several years ago, supports the general thrust of the assessment this paper is suggesting, though it differs on some of the causes. The study by Nicholas Becquelin (2000:54, 90) concludes that the '1990s led to a very major shift in relations between the state and society in Xinjiang'. The system had changed, the author suggested, from one that discriminated (presumably positively) on the basis of nationality to one that segregated on the basis of nationality. The study identified major risks in Beijing's current strategy in the XUAR, and described the heightening of inter-ethnic 
conflicts-and in southern Xinjiang in particular, a renewed repressive climate and increased segregation. (The Becquelin study appears to differ from this paper in its emphasis on new Han migration into Xinjiang, whereas this paper has reported a net outflow of Han Chinese. Becquelin does note that 'information on recent Han arrivals is extremely difficult to verify'.)

${ }^{16}$ See Seymour (2000). Seymour notes that the Corps is a 'major institution for the ethnic Han (Chinese) colonisation of Xinjiang'. 'Although quasi-military in origin, its military role is now eclipsed by its economic role. Traditionally it was primarily a collection of state farms, but in recent years its industrial enterprises have expanded. It has also played a role in imprisoning convicts from eastern China. Largely destroyed during the Cultural Revolution, it was actually abolished for a few years beginning in 1975. But the perceived need to project Chinese influence into the area, and to protect against ethnic unrest and Soviet pressures, persuaded the authorities that the Corps should be revived. Today the Corps has 2.8 million members, or 14 per cent of Xinjlang's population, and plays a significant role in the region's economy'. According to the Uighur American Association, the Corps has a special legal status that subordinates it to Beijing, not to the Autonomous Regional government; the Corps plays an integral part in Beijing's strategies for control of the region; and the Corps' exploitative activities are the main source of the 'ethnic' rebellion in the XUAR (Uyghur American Association n.d.).

${ }^{17}$ Interviews with the author, October 2000.

18 UNSC Resolution 1214, 8 December 1998; Resolution 1267, 15 October 1999; Resolution 1333, 19 December 2000.

19 See, for example, Ba Ren (2001:n.p.). Two excerpts are indicative: 'To China, it means that the US fills the last gap in the northeast of its ring of encirclement (or at least hammers in a wedge). If the US uses the opportunity to occupy Afghanistan, or set up a puppet government in that country, the US military stationed in Afghanistan and in the Persian Gulf will take up two corners, and possibly use national and religious factors to give strategic pressure on China's western region. China will feel prickles down his back...To summarise the above, if the US military marches into Afghanistan, the strategic situation as a result of the military actions will greatly change, accelerate the demolition of the original power balance in Central Asia, and make Central Asia a region with a prominently unbalanced security mechanism in the world. We should attach enough importance and be vigilant to this possible variable of the international security situation that has an effect on China.'

o See, for example, Xinhua Domestic Service, 3 August 1997, carried in FBIS-CHI-97-217: 'US Central Asian strategy faces challenges'.

27. The members are China, Russia, Tajikistan, Kyrgyzstan, Kazakhstan (the original Shanghai Five) and Uzbekistan. The negotiations built on significant progress that had been made between China and the USSR before 1991. 
2 See Article 2 of the Declaration on the Creation of the Shanghai Cooperation Organisation.

${ }^{23}$ See Article 5.

${ }^{24}$ See International Crisis Group (2003). The present author was the principal author of that ICG report.

\section{REFERENCES}

Arkin, W.M., 2002. 'Secret plan outlines the unthinkable', Los Angeles Times, 10 March.

Austin, G., 1997. 'The Taiwan issue in Japanese domestic politics', in Austin, G. (ed.), 1997. Missile Diplomacy and Taiwan's Future: Innovations in Politics and military power, Canberra Papers in Strategy and Defence, Strategic and Defence Studies Centre, The Australian National University, Canberra.

- 1998. China's Ocean Frontier: international law, military force and national development, Allen \& Unwin, St Leonards.

- 2003. 'Philippines Spratly policy as a case study in conflict enhancement', Security Dialogue, 34(1):41-54.

Australian Strategic Policy Institute, Beyond Bali: ASPI's strategic assessment, 2002, Australian Strategic Policy Institute, Canberra. Available online at http:// www.aspi.org.au/beyondbali/2.html.

Ba Ren, 2001. 'The United States meddles with Afghanistan to kill three birds with one stone: on the White House's military deployment and variable of Central Asian strategic patterns', Ta kung pao (Internet version), 24 September. Reprinted in FBIS-CHI-2001-0924.

Becquelin, N., 2000. 'Xinjiang in the 1990s', China Journal, 44:65-90.

Embassy of the People's Republic of China in Australia, 2002. Full text of Jiang Zemin's Report at $16^{\text {th }}$ Party Congress, Chinese Embassy to Australia, Canberra. Available online at www.chinaembassy.org.au/eng/37883.html.

Government of the United States of America, 2002. The National Security Strategy of the United States, White House, Washington, DC. Available online at http:// www.whitehouse.gov/nsc/nssall.html [accessed September 2002].

International Crisis Group, 2003. Taiwan Strait III: the path to peace, International Crisis Group, Brussels. Available online at www.crisisweb.org [accessed June 2003].

Kemenade, W.V. and Webb, D., 1998. China, Hong Kong, Taiwan, Inc, Vintage, New York. 
Knaus, J.K., 2000. 'An uncertain ally: the US government and Tibet', Harvard Asia Quarterly, 4(3):n.p. Available online at www.fas.harvard.edu.

Lampton, D.M. and May, G.C., 1999. Managing US-China Relations in the TwentyFirst Century, The Nixon Center, Washington, DC. Available online at www.nixoncenter.org.

PRC State Council Information Office, 2002. China's National Defense in 2002, Full Text of White Paper issued by the PRC State Council Information Office, 9 December. Reprinted by FBIS-CHI-2002-1209: 'Full Text of China's National Defense White Paper'.

Seymour, J.D., 2000. 'Xinjiang's production and construction corps, and the sinification of Eastern Turkestan', Inner Asia, 2(2):171-93.

South Asia Analysis Group, 1999. Continuing Unrest in Xinjiang: an update, South Asia Analysis Group, Noida. Available online at www.saag.org/papers [accessed 14 March 1999].

Uyghur American Association, n.d. Bingtuan: Xinjiang production and construction Corp, Uyghur American Association, Virginia. Available online at http:// www.uyghuramerican.org/ET/bintuan/mainpage.html.

Watson, F., 1966. The Frontiers of China, Chatto and Windus, London.

Zhu, T., 2001. 'Nationalism and Chinese foreign policy', The China Review, 1(1):127. 